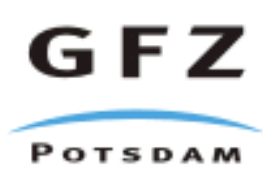

Originally published as:

Brachert, T. C., Reuter, M., Felis, T., Kroeger, K. F., Lohmann, G., Michaels, A., Fassoulas, C. (2006): Porites corals from Crete (Greece) open a window into Late Miocene (10Ma) seasonal and interannual climate variability. - Earth and Planetary Science Letters, 245, 1-2, 81-94

DOI: 10.1016/j.epsl.2006.03.005. 
Earth and Planetary Sciences Letters, 245: 81-94 (2006)

DOI 10.1016/j.epsl.2006.03.005

\section{Porites corals from Crete (Greece) open a window into Late Miocene (10 Ma) seasonal and interannual climate variability}

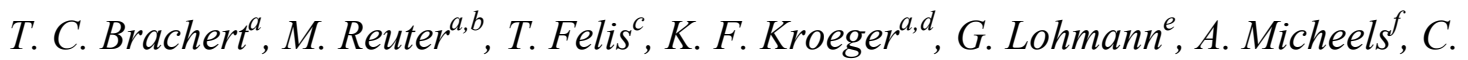
Fassoulas $^{g}$

${ }^{a}$ Institut für Geowissenschaften, Johannes Gutenberg-Universität Mainz, Becherweg 21, 55099 Mainz, Germany

${ }^{c} D F G$-Forschungszentrum Ozeanränder, Universität Bremen, Gebäude GEO,

Klagenfurter Str., 28359 Bremen, Germany

${ }^{e}$ Alfred-Wegener-Institut für Polar- und Meeresforschung, Bussestr. 24, 27570

Bremerhaven, Germany

${ }^{f}$ Institut für Geowissenschaften, Sigwartstraße 10, 72076 Tübingen, Germany

${ }^{g}$ Natural History Museum, University of Crete, 71409 Iraklion, Greece 
*Correspondence and requests for materials should be addressed to T.C.B. (e-mail: t.brachert@geo.uni-mainz.de)

Present addresses:

${ }^{b}$ Karl-Franzens-Universität Graz, Institut für Erdwissenschaften, Bereich Geologie und Paläontologie, Heinrichstr. 26, 8010 Graz, Austria

${ }^{d}$ Geoforschungszentrum Potsdam, Sektion 4.3, Telegraphenberg, 14473 Potsdam, Germany 


\section{Abstract}

Variations in the biotic composition of marine shallow water carbonates document global climatic changes. However, a discontinuous stratigraphic record and uncertainties regarding the ages limit the significance of shallow water carbonates as palaeoclimatic archives on geological time-scales. Notwithstanding these deficits, the environmental information stored in the skeleton of reef biota is a unique source of information that resolves seasonal to interannual climate variability in geological time. Application of the method to corals from carbonate rocks is usually restricted to the past 130,000 years, because the aragonite skeleton undergoes rapid diagenetic alteration. Consequently, reconstructions resolving seasonal to interannual climate variability of the more distant geological time are rare. We describe exceptionally well preserved corals (Porites) as old as Late Miocene (10 million years) from the island of Crete (eastern Mediterranean, Greece). Stable isotope records $\left(\delta^{18} \mathrm{O}, \delta^{13} \mathrm{C}\right)$ reflect seasonal changes in sea surface temperature and symbiont autotrophy. Spectral analysis of a 67 years coral $\delta^{18} \mathrm{O}$ record reveals significant variance at interannual time-scales ( 2 - 5 years) that show similarities to Late Quaternary eastern Mediterranean climate variability. Supported by simulations with a complex atmospheric general circulation model coupled to a mixed-layer ocean model, we suggest that climate dynamics in the eastern Mediterranean may reflect atmospheric variability related to the Icelandic Low 10 million years ago.

Keywords: Coral record, stable isotopes, interannual climate variation, climate model, Late Miocene, Crete, Greece 


\section{Introduction}

Our present understanding of the global climate evolution during the Cenozoic era was unlocked principally from deep sea sedimentary archives using environmental proxy data reflecting global ice build-up [1, 2], water temperature [3], weathering history [4], and carbonate patterns [5]. For the Neogene period, this record allows to tackle insolation changes as pacemakers of palaeoenvironmental changes [6] and to establish a quantitative chronostratigraphic framework on orbital time-scales [7]. In shallow water environments carbonate secreting biota are highly sensible to sea surface temperature (SST), salinity and nutrient concentrations [8] and, therefore, have potential to document climate changes in the geological record $[9,10]$. However, systematic application of the method in palaeclimatology is limited, because upon crossing certain critical environmental thresholds, the shallow water systems tend to switch from one stable condition into an other, and the nature of the palaeoclimatic record of shallow water carbonates remains largely qualitative $[11,12]$. In addition, Cenozoic carbonate platform data suffer from a discontinuous sedimentary record and a limited precision in age models $[13,14]$. Notwithstanding these limitations, the environmental information stored in the skeleton of huge scleractinian corals may add a new dimension to our understanding of the Cenozoic climate system, because the massive skeletons of colonial corals represent archives of past SST, salinity (SSS) and productivity that resolve interannual to subannual time-scales. In historic and prehistoric time, the coral record has therefore proven to be an important source of information to study seasonality and climatic variations on interannual to interdecadal time-scales [15-18]. However, the aragonite coral skeletons are susceptible to various types of mineralogical and geochemical alteration, and corals older than the Pleistocene are generally recrystallized and transformed from original aragonite into secondary calcite $[19,20]$. 
In this paper, we present seasonally-resolved environmental proxy records using fossil Porites corals found in sediments of early Late Miocene age (10 Ma, Tortonian) on the island of Crete (eastern Mediterranean Sea; Fig. 1). The massive coral skeletons have retained their original aragonite mineralogy, microstructure and skeletal porosity [21]. In cross sections and $\mathrm{x}$-ray photographs, conspicuous growth increments represent annual density bands known from modern Porites. Growth rates were $\sim 4 \mathrm{~mm} / \mathrm{year}$ and similar to massive Porites from modern high-latitude reefs [22], which reflects the position of Crete at the northern margin of the Late Miocene reef belt [23], and the warmer than present Late Miocene greenhouse climate [2]. Although the Late Miocene palaeoceanography and palaeoclimatic evolution of the Mediterranean is well known on geological time-scales [7, 24, 25], little information exists with regard to the subannual and interannual climate variability. For the eastern Mediterranean and Middle East, the Arctic Oscillation/North Atlantic Oscillation (AO/NAO), the Northern Hemisphere's dominant mode of atmospheric variability [26, 27], exerts not only a major impact on the present-day interannual climate variability, but has also played a critical role during the Holocene and Last interglacial [28-31]. We have analysed a marine coral stable isotope record $\left(\delta^{18} \mathrm{O}\right)$ from the Miocene of Crete that covers a time-span of 67 years. Our combined approach based on the coral proxy data and model simulations for the Tortonian using the ECHAM4/ML climate model for a world without Greenland ice shield $[32,33]$ provides unique insights into atmospheric variability at interannual timescales in the European/Mediterranean region 10 Ma ago.

\subsection{Geological context}


Following the greenhouse climate of the Middle Miocene, stepwise cooling and incipient glaciation of the northern hemisphere took place during the Late Miocene [2]. During the Late Miocene, 10-5 million years ago, the global palaeogeography and plate mosaic arrived at the main traits of the present-day situation. Although at a somewhat more southward position $\left(1-3^{\circ}\right.$ latitude [45]), the general palaeogeography of the Mediterranean Sea was similar to the present-day: it formed a marginal sea of the Atlantic Ocean framed by uplifting mountain ranges. An ephemeral sea strait intermittently linked the eastern Mediterranean via the Aegean with the Paratethys to the north of the alpine orogen system [46]. Coral reef growth over most shallow water zones of the ancient Mediterranean Sea and a subtropical vegetation [47], is the obvious local expression of a globally warm climate [2]. During the earliest Tortonian, in the central Mediterranean province, almost no true reefs but isolated non-framework communities of Porites and Tarbellastrea occurred, and no zooxanthellate corals nor reefs existed to the west of the Betic-Rifan chain in the Atlantic, nor in the northernmost Mediterranean Sea and the Paratethys, whereas coral reef growth has been documented only in the western and eastern Mediterranean area. This biogeographic pattern and the remarkably low diversity of reef corals (domination by Porites and Tarbellastrea) are generally believed to reflect a position of the Mediterranean at the northern limit of the global coral reef belt $[11,23]$.

On astronomical time-scales, the eastern Mediterranean oceanography was repeatedly affected by monsoon $[25,48]$. However, with regard to the overall similarity of the palaeogeography with the present-day, there might have been a marked influence of the Atlantic domain on eastern Mediterranean climate via atmospheric teleconnections and ocean circulation patterns [28-31, 44, 49]. 


\subsection{Late Miocene coral environments}

The Tortonian rock section of central Crete starts with clastics of the Ambelouzos Formation [50]. Depositional environments were brackish lagoons and marginal marine environments. Coarse clastic sediments formed along the coastline, which were intermittently colonized by corals forming isolated reef patches and laterally extensive carpets. The coral constructions can be taken as an indicator of winter SST not colder than $18^{\circ} \mathrm{C}$ [22]. Consistently, terrestrial floras document a warmer, but also a more humid climate than in present-day Crete with a maximum of precipitation during the winter [47]. Stratiform lignite concentrations within some segments of the formation strikingly document moist climatic conditions, however, a bed with pedogenic lenticular gypsum implies a shift from moist to dry climatic conditions over geological time-scales during the Tortonian. The Ambelouzos Formation is covered by the more calcareous Varvara Formation of early Messinian age (latest Miocene). The early Messinian palaeobotanical record documents successive climatic drying $[51,52]$ but temperatures remained sufficiently warm as to sustain reef growth [21, 53]. Finally, a thick gypsum unit at the top of Varvara Formation implies environmental restriction in a very dry environment for the late early Messinian [50].

The patterns of early Tortonian coral growth have been studied near the towns of Ambelouzos and Agia Varvara, Rouvas municipality (Fig. 1). Laterally extensive beds formed by branching or massive corals (Porites and Tarbellastrea) intercalate and interfinger with conglomerate and sandstone or siltstone of the Ambelouzos Formation formed in coastal environments [50]. Near the small town of Psalidha, the corals form sheet-like bodies of metre thickness with no distinct ecological zonation (carpets or biostromes) (Fig. 2). The biostromes are stacked vertically to form a carbonate build-up 
with a simple layer-cake stratigraphy [21], which has been assigned a Sr-isotope age of $10 \mathrm{Ma}$ [54]. The density, fabric and topography of the last coral biostrome are well preserved by a drape of a poorly classified sandstone and conglomerate with a high amount of silt. Whereas most of the corals of the build-up have been transformed into calcite, some corals of the uppermost biostrome situated along the contact with the hangingwall sandstone/conglomerate have fully retained their original aragonite mineralogy, microstructure and skeletal porosity (Fig. 2) [21]. From the large size $(1 \times 1 \times 2 \mathrm{~m})$ and massive growth forms of Porites and Tarbellastrea within this carpet we infer a water-depth of less than $20 \mathrm{~m}[55,56]$.

\subsection{Methods}

Two sites with aragonite corals have been found in central Crete near the ancient town of Psalidha (Fig. 1). Site 1 is located in a grove with olive-trees, where recently ploughing has brought to surface abundant centimetric fragments of corals (Porites, minor Tarbellastrea). Site 2 is an outcrop at the top of the Psalidha coral build-up with decimetric corals preserved in growth position. There, a geological section was measured and lithologies were classified according to biofacies and primary sedimentary textures. According to fine-scale geological mapping, both coral sites are in the same stratigraphic position at the top of Psalidha build-up (Fig. 1).

The fragile aragonite coral skeletons from site 2 were embedded in polyurethane foam to prevent disintegration during sampling, transportation and splitting. Slabs and thinsections of corals were stained with Feigl's solution to reveal the distribution of aragonite and calcite [34]. Aragonite and calcite concentrations were measured by x-ray 
diffraction using a Seifert XRD 3000 diffractometer (Mainz University, H.-D. Werner). Samples were scanned from $2 \theta$ of $20^{\circ}$ to $60^{\circ}$. In small specimens, one sample was taken for $\mathrm{x}$-ray diffraction (P1, P3, P4), and in a large coral (P2) 5 samples were taken at random distances. Under the SEM, broken and polished surfaces of the corals were analysed for ultrastructures. X-ray photographs were taken from slabs cut to an equal thickness of $6 \mathrm{~mm}$ at the Research Center for Ocean Margins, University of Bremen, to reveal annual density bands and potential recrystallization effects or cements.

From a total of 32 coral specimens three samples were selected for a detailed stable isotope study according to visibility and thickness of the growth bands (P 2, P 3, P 4). Sampling for stable isotope analysis was performed along transects following the most rapidly extending primary growth axes in order to minimize variation through potential kinetic isotope effects [35]. Small $(<10 \mathrm{~cm})$ coral specimens were mounted on a scaled movable table below a micro miller to allow for accurate, continuous equidistant sampling (depth and distance $1.0 \mathrm{~mm}$, diameter of drill bit $1.0 \mathrm{~mm}$ ). One large coral fragment (P 2, size $30 \times 45 \mathrm{~cm}$ ) was selected to produce a multidecadal isotope record. Abundant open, uncemented fractures let this specimen appear too fragile to be sliced for x-ray photography and to be mounted on the movable table of the micromiller. Therefore, a composite transect of $24.5 \mathrm{~cm}$ length was selected according to visual inspection of the growth bands in reflected light and preservation state of the skeleton. Sampling distance was estimated visually for "continuous point sampling" using a micromiller attached to a movable stand and equipped with a $0.6 \mathrm{~mm}$ drill bit. Due to hole breakouts final borehole diameter was $\sim 0.9 \mathrm{~mm}$ producing the minimum amount of carbonate powder required for stable isotope analysis $\left(\delta^{18} \mathrm{O}, \delta^{13} \mathrm{C}\right)$ in a quarterly resolution. As compared to modern Porites, the skeleton of our Miocene specimens is gracile and very porous. Acquisition of sufficient amounts of carbonate powder was therefore the main limitation to high sample resolutions. Stable isotope analysis was performed by M.M. Joachimski (Erlangen University, Germany). Carbonate powders 
were reacted with $100 \%$ phosphoric acid at $75^{\circ} \mathrm{C}$ using a Kiel III online carbonate preparation line connected to a ThermoFinnigan 252 masspectrometer. All values are

reported in per mil relative to V-PDB by assigning a $\delta^{13} \mathrm{C}$ value of $+1.95 \%$ and a $\delta^{18} \mathrm{O}$ value of $-2.20 \%$ to NBS19. Reproducibility was checked by replicate analysis of laboratory standards and is better than $\pm 0.03 \%$ o $(1 \sigma)$. SST and SSS variations were calculated according to published equations [31, 36, 37].

Age models were based on banding couplets and were calibrated against the most positive oxygen isotope values measured per annual cycle. A multidecadal coral record (P2) was constructed from a total of 5 isolated transects by visual correlation of growth bands and overlapping isotope patterns. The multidecadal master chronology was selected for spectral analysis to detect potential interannual cyclicity. Prior to spectral analyses [38] the original data set was transformed into an equally spaced time-series of four samples per year [39] (quarterly resolution), detrended and normalized.

To investigate the physical mechanisms behind the documented interannual climate variability in our coral proxy records from Crete and to put it into a large-scale climatic context, we analyzed a simulation with a complex atmospheric general circulation model coupled to a mixed-layer ocean model (ECHAM4/ML) for Tortonian conditions $[32,33]$. The spatial resolution of the ECHAM model was T30 $\left(3.75^{\circ} \times 3.75^{\circ}\right)$ with 19 levels for the vertical domain. The set of surface boundary conditions of the Tortonian simulation included a generally lower orography and a reconstructed vegetation which was characterized by a generally larger forest cover than today [32, 33]. Moreover, continental ice was removed on the northern hemisphere (e.g. no Greenland ice shield), the land-sea distribution referred to modern conditions, and the atmospheric $\mathrm{CO}_{2}$ was set to the present-day value of $353 \mathrm{ppm}[32,33,40,41]$. To account for a generally weaker palaeoceanic heat transport such as represented in Miocene ocean model studies 
$[42,43]$, the flux correction of the constant depth 50m-slab ocean model was adjusted for the Tortonian simulation [33]. Miocene surface ocean circulation was not affected by the shape of the Mediterranean basin [44].

\section{Results}

\subsection{Preservation of coral skeletons selected for stable isotope study}

At two locations of the Psalidha build-up, the corals were sampled for detailed petrographic and geochemical investigation (Sites $1 \& 2$; Fig. 1, 2). At Site 2 of Psalidha locality, a massive in situ Porites has been found, which measures 1x1x2 $\mathrm{m}$ in size and which has fully retained its original aragonite mineralogy and skeletal microstructures in our samples. The massive skeleton is formed of smaller, $5-10 \mathrm{~cm}$ wide, laterally fused columns with convex-upward hemispheric growth surfaces (Fig. 3). The skeleton exhibits fractures, which preferentially formed parallel to the contacts of the individual columns. Some of the fractures are filled with light grey, cryptocrystalline carbonate, whereas a second generation of fractures has remained open. Precipitates and detrital materials, however, are confined to the fractures and do not extend into the adjacent skeleton (Fig. 4).

In reflected light, conspicuous "light" and "dark" bands with a wavy form reflect the fused-columnar to protuberant growth form of the massive Porites colonies. According to x-ray photographs, the couplets of "light" and "dark" bands correspond with alternating zones of high and low skeletal density (Fig. 4, 5A, B). The banding couplets seen in reflected light and x-radiographs, therefore, have been assigned to the annual 
growth increments well documented from modern Porites corals [57]. Correspondingly, the various pieces of coral recovered span periods of 4 years to a maximum of 67 years. Growth rates remained at $\sim 4 \mathrm{~mm} /$ year and compare well with Porites from modern high-latitude reefs $[22,58,59]$.

In thin-section, the skeleton shows a pristine type of preservation, with radially arranged bundles of aragonite fibres emerging from centres of calcification. Thin basal diaphragms (dissepiments) forming meniscate bridges within the skeleton are clearly visible. Diagenetic overgrowths and recrystallizations are not visible at this magnification and are therefore volumetrically not significant (Fig. 5A, B). SEM micrographs reveal the surface of the skeleton to be either smooth or ragged, the latter due to low crystal overgrowths (Fig. 5C, D, F). On the smooth surfaces of the skeleton boundaries of fasciculi bundles are clearly visible (Fig. 5E), however, distal faces of acicular crystals are smooth and edged showing no sign of dissolution [cf. 60] (Fig. 5E). An exception might be the blunt pitted terminations of the crystals themselves (Fig. 5E). Due to the complex curved morphology and smooth overall character, these skeletal surfaces are interpreted to have formed in immediate contact with the calcioblastic tissue of the coral [19], and to have no later overgrowth of cements. Similarly, the tiny aragonite crystals $(1-2 \mu \mathrm{m})$ of the dissepiments do not exhibit any evidence for significant dissolution nor significant overgrowth (Fig. 5F). Tips of syntaxial aragonite cements $(1-2 \mu \mathrm{m})$ forming thin crusts are interpreted to represent marine cement formed deeper in the coral, after withdrawal of the calcioblastic tissue from the skeleton during growth [61], however, volumetrically insignificant (Fig. 5F). In SEM view, fracture surfaces of the skeleton reveal a pristine aragonite texture with radial arrangement of aragonite fibres. However, centres of calcification and boundaries of fasciculi bundles appear to be more or less enlarged (Fig. 5C, D), which both indicates that the skeleton 
has been affected by some dissolution that typically started along the centres of calcification [21, 62]. Microborings have no infill with cement (Fig. 5D). Calcite cements are not visible within the skeleton, apart from cryptocrystalline carbonate infilling fractures (Fig. 4B), and skeletal stable isotope compositions $\left(\delta^{18} \mathrm{O}, \delta^{13} \mathrm{C}\right)$ are reset only immediately adjacent to the fractures [21]. Consequently, calcite concentrations are below the detection limits of the $\mathrm{x}$-ray diffraction method in all samples $(<1 \%)$, which reflects a very pristine stage of preservation, despite the age of these corals is $10 \mathrm{Ma}$. Therefore, although some dissolution has occurred, original stable isotope signatures have been expected to be preserved (cf. [63, 64].

\subsection{Coral stable isotope records}

From both coral sites a total of three corals was selected and sampled for stable oxygen $\left(\delta^{18} \mathrm{O}\right)$ and carbon $\left(\delta^{13} \mathrm{C}\right)$ isotope analysis (P 2, P 3, P 4; Fig. 1). The small coral fragments P3 and P4 were chosen, because they document high annual growth rates. Sampling at even $1 \mathrm{~mm}$ increments allowed for a quarterly (P 4) and bimonthly (P 3) resolution, and time series of 12 and 4 years length, respectively. In all records, the stable isotope patterns are within the same spectrum of variation: The mean $\delta^{18} \mathrm{O}$ composition found within the short records of corals P3 (-2.59\%) and P4 (-2.96 \%) are within the variation present in the 67 years record of coral P2 (-2.69\%; Fig. 6, 7). Coral P2 was selected because of its large size and 67 years of record, even though its slow rate of growth as compared to corals $\mathrm{P} 3$ and $\mathrm{P} 4$. Continuous point sampling, resulted in an average resolution of $\sim 3.7$ samples/year, providing a near-quarterly resolution time series. 
The coral $\delta^{18} \mathrm{O}$ signatures exhibit a cyclic signal which consistently reflects the couplets of annual growth bands: maxima coincide with light bands in reflected light or highdensity bands in x-ray photographs, minima with corresponding low-density bands. In the high-resolution record (coral P3, P4), the $\delta^{18} \mathrm{O}$ signal is commonly a series of $\mathrm{U}$ shaped arcs and is not necessarily a sinusoidal curve, because maxima are forming narrow peaks (Fig. 6A, B). Coral $\delta^{13} \mathrm{C}$ shows a correlation with the density couplets as well, but is usually phase-shifted relative to $\delta^{18} \mathrm{O}$ by about a half isotope cycle. The minima in $\delta^{13} \mathrm{C}$ consistently precede the maxima in $\delta^{18} \mathrm{O}$ by one data point, i.e. $\sim 2$ months (Fig. 6A). Two parallel records at $3 \mathrm{~cm}$ distance analysed with a quarterly resolution (P4) reproduce the isotope patterns, and perfectly fit with the density bands (Fig. 6B, C). Thus, a quarterly resolution of the isotope records is fully sufficient as to document Tortonian seasonality (Fig. 6).

A large coral (P 2; Fig. 3) provides a near-quarterly resolution $\delta^{18} \mathrm{O}$ time series for a time window of 67 years. Apart from an overall $\delta^{18} \mathrm{O}$ decrease in the order of $-0.5 \%$ over the 67 years, the interannual coral $\delta^{18} \mathrm{O}$ variations are in the order of 0.3 to $0.5 \%$ (Fig. 7). As documented in the short parallel transects, a quarterly resolution was found to give sufficiently similar isotope records (Fig. 6) and, therefore, to properly document late Miocene seasonal and interannual variability. This observation is consistent with interpretations of interannual variability documented at a quarterly resolution in modern coral records [70].

\section{Discussion}

3.1 Environmental interpretation of the coral stable isotope records 
The couplets of light and dark bands so conspicuous in reflected light are consistent with the density banding detected in X-ray photographs (Fig. 4, 5) and the stable isotope patterns (Fig. 6): Light bands in reflected light are equal the with zones of high skeletal density and correspond to the more positive $\delta^{18} \mathrm{O}$ values of an annual cycle. They therefore reflect the suboptimal growth season, i.e. the winter, whereas the thick dark bands (reflected light) of low skeletal density correspond to the more negative $\delta^{18} \mathrm{O}$ values and therefore represent the summer. The asymmetric, series of arc-type oxygen isotope patterns implies, that the cold season is underrepresented due to slow growth ([65]; Fig. 6A, B). The relationships between coral $\delta^{18} \mathrm{O}, \delta^{13} \mathrm{C}$ and the density banding pattern are identical to those of modern, shallow-water Porites from the nearby northernmost Red Sea $[29,66,67]$. This arid region is the nearest modern analogue and is assumed to represent similar climatic/oceanographic conditions (high-latitude reefs, maximum sunshine in summer, and clouds and rain in winter). Although palaeobotanical records and lithological information from the Ambelouzos Formation document extreme hydrological variation over geological time-scales, pure carbonate sediments preferentially formed in a rather dry climatic context [53]. Therefore, and because mean coral $\delta^{18} \mathrm{O}$ seasonality in the Crete record (1.14\%; Fig. 6) is in the same order of magnitude as in last interglacial Porites from the northernmost Red Sea $\left(1.27 \% / 8.4^{\circ} \mathrm{C} ;[31]\right)$, we assume that the $\delta^{18} \mathrm{O}$ seasonality in the Crete corals is largely controlled by temperature, which would suggest an average SST seasonality of $7.5^{\circ} \mathrm{C}$ [31] for the eastern Mediterranean during the Tortonian (Fig. 6). According to Hofrichter [68], the present-day eastern Mediterranean undergoes minor seasonal salinity changes as well $\left(<0.5 \%\right.$, equivalent with $\sim 0.14 \%{ }^{18} \mathrm{O}_{\mathrm{VPDB}}$ seawater change [37]), but has a more pronounced SST seasonality $\left(\sim 9^{\circ} \mathrm{C}\right.$ equivalent with $\sim 1.4 \%$ $\delta^{18} \mathrm{O}_{\mathrm{VPDB}}$ change in Porites [31]), which we explain in terms of a slightly more southward position of the Mediterranean and globally warmer climate during the Tortonian $[2,45]$. 
The seasonal range of variation in coral $\delta^{13} \mathrm{C}$ and phase shift relative to $\delta^{18} \mathrm{O}$ is interpreted to reflect changes in autotrophy of the coral [69], i.e. less photosynthesis due to less sunshine in the suboptimal season and, second, a shallow water setting [67]. The latter reconstruction fits the general concepts of Miocene Mediterranean coral zonations $[55,56]$. Although on an annual scale, light intensity and SST are positively correlated, minimum winter temperatures lagged behind the minimum in light intensity by about two months (one sample increment). An analogous pattern has been described from the northernmost Red Sea, where annual light minima exist in winter (December February), whereas the lowest SST have been encountered during March [66]. All in all, these findings rule out the possibility of significant diagenetic modifications of the skeleton with respect to stable isotope ratios, because diagenesis tends to homogenize isotope signatures [62].

The $\delta^{18} \mathrm{O}$ long-term trend and interannual variability may reflect not solely variations in SST but also in $\delta^{18} \mathrm{O}_{\text {seawater }}$ as a result of variations in the hydrologic balance and related discharge in the marginally marine environment where the corals were growing. In addition, the 67 years record in $\delta^{18} \mathrm{O}(\mathrm{P} 2)$ fully explains the deviating mean and absolute ranges of $\delta^{18} \mathrm{O}$ within the two short time series (P3, P4; Fig. 6, 7). The presence of such a consistent spectrum of variation in $\delta^{18} \mathrm{O}$ records from both coral sites suggests forcing by a specific climatic system variation during growth of the Psalidha build-up in the eastern Mediterranean area. Interannual $\delta^{18} \mathrm{O}$ changes of the same order of magnitude were documented in Quaternary Porites from the northernmost Red Sea and the western tropical Pacific [31, 71]. 


\subsection{Spectral analysis}

Multitaper method spectral analysis of the coral $\delta^{18} \mathrm{O}$ time series (P2) reveals significant variance at periods of 2.2 and 4.7 years reflecting interannual variations in SST and/or hydrologic balance in the eastern Mediterranean during growth of the Psalidha build-up (Fig. 8). From the Neogene of the Mediterranean area, this is the only record of seasonal and interannual climate variability so far. Interestingly, proxy records (Porites, tree rings) of eastern Mediterranean/Middle East climate for the last interglacial, the late Holocene and the past centuries consistently show significant variance at periods of 2.12.4, 3.2-3.4 and 5-6 years [28, 29, 31]. The coral-based results from Crete therefore suggest that time-scales of interannual climate variability in the eastern Mediterranean during growth of the Psalidha build-up may have similarities to the present.

\subsection{Modelling Tortonian climate}

The modelled surface air temperature anomalies indicate warmer winters during the Tortonian relative to the present in northern Europe and in the western and eastern parts of the Mediterranean basin, but cooler winters over the Atlantic. This result is consistent with the spatial distribution of earliest Tortonian coral reefs, non-framework colonial coral communities and cool water carbonates (Fig. 9A) [53, 59, 72-75]. Interestingly, the interannual variability of modelled eastern Mediterranean winter SST during the Tortonian is linked to a spatial pattern in the modelled sea level pressure field that resembles the present-day Icelandic Low (Fig. 9B), one of the centres of action of the $\mathrm{AO} / \mathrm{NAO}$. As compared to today, the Icelandic Low in the model is displaced southwards and more pronounced relative to the Azores High. The model suggests that 
the interannual SST variability documented in our Tortonian coral record from Crete was linked to the variability of the Icelandic Low, which controlled the intensity of the westerlies bringing relatively warm oceanic air from the Atlantic to the Mediterranean (Fig. 9B).

The interannual variability in the Tortonian coral $\delta^{18} \mathrm{O}$ record does not solely reflect variations in SST but also in the hydrologic balance. Consistent with the modelled winter SST results, the interannual variability of modelled eastern Mediterranean winter evaporation is linked to the variability of the Icelandic Low (Fig. 9C). The model suggests that the physical mechanism is provided by a high-pressure anomaly over southern Eurasia that in turn is related to variations of the Icelandic Low. The highpressure anomaly controls the advection of relatively dry continental air from northern Arabia towards the eastern Mediterranean.

\section{Conclusions and implications}

Corals recovered from the top of the Psalidha build-up (early Tortonian, $10 \mathrm{Ma}$, central Crete) have fully retained their original microstructure, aragonite mineralogy and stable isotope composition. Growth bands visible in polished slabs and density bands observed in $\mathrm{x}$-ray photographs are in phase with variations in $\delta^{18} \mathrm{O}$ and $\delta^{13} \mathrm{C}$. The banding, therefore, is interpreted to reflect seasonal environmental variability. Seasonal $\delta^{18} \mathrm{O}$ and $\delta^{13} \mathrm{C}$ variation, however, is phase shifted and reflects seasonality in SST, seawater composition and symbiont autotrophy known from modern shallow water corals. Beyond seasonal environmental variability, a 67 years coral $\delta^{18} \mathrm{O}$ record documents for the first time Miocene interannual SST fluctuations and/or changes of the hydrologic 
balance, with significant variance at time-scales of 2.2 and 4.7 years. A simulation with a climate model showed that interannual variability of SST and hydrologic balance in the eastern Mediterranian during the Tortonian were controlled by atmospheric variability associated with the Icelandic Low and a high pressure area over southern Eurasia. Our combined coral- and model-based study may therefore suggest atmospheric variability with similarities to the present over the Northern Hemisphere 10 million years ago, in a period when the Greenland ice sheet did not exist. The possible future retreat of the Greenland ice sheet $[76,77]$ along with an expected global temperature increase of 1-2 $\mathrm{K}$ within the next centuries [78] might provide a possible analogous situation to the Tortonian, for which a similar temperature difference from today has been estimated [79].

Clearly, more proxy records that resolve seasonal to interannual climate variability and that allow to separate temperature from seawater effects on coral $\delta^{18} \mathrm{O}$ are needed in the future to establish Late Miocene climate patterns. However, our study highlights the important contribution that the analysis of shallow water carbonate systems can make to Neogene palaeoclimatology and palaeoceanography, and our findings support the idea of the Tortonian as a period for cross-validation of palaeoclimate reconstructions and climate models to successfully predict future climate.

Acknowledgements: The Gergeri administration in central Crete (Rouvas Municipality) is thanked for their generous support during the recovery of the samples and for providing the working permits. M. Selinger generously helped with cutting the large coral samples at the Steinmetz-Berufsbildungszentrum, Mainz, Germany. Michael M. Joachimski (Erlangen, Germany) performed the stable isotope analyses, and H.-D. Werner (Mainz, Germany) the x-ray diffraction analyses. Florian Böhm (Kiel, Germany), Thomas Grießemer, Michael Maus, Bert Rein (all Mainz, Germany) and Helen V. McGregor (Bremen, Germany) gave valuable comments and support. T.F. acknowledges support through DFG-Research Center 'Ocean Margins' at Bremen University (contribution no. RCOM0376). This work was funded by the Deutsche Forschungsgemeinschaft (DFG, Germany) through grant Br 1153/7 (T.C.B., M.R.). 


\section{$\underline{\text { References }}$}

[1] K.G. Miller, J.D. Wright, R.G. Fairbanks, Unlocking the ice house: OligoceneMiocene oxygen isotopes, eustasy, and margin erosion, Journal of Geophysical Research 96(1991) 6829-6848.

[2] J. Zachos, M. Pagani, L. Sloan, E. Thomas, K. Billups, Trends, rhythms, and aberrations in global climate 65 Ma to present, Science 292(2001) 686-693.

[3] K. Billups, D.P. Schrag, Paleotemperatures and ice volume of the past $27 \mathrm{Myr}$ revisited with paired $\mathrm{Mg} / \mathrm{Ca}$ and ${ }^{18} \mathrm{O} /{ }^{16} \mathrm{O}$ measurements on benthic foraminifera, Paleoceanography 17(2002).

[4] M.E. Raymo, W.F. Ruddiman, Tectonic forcing of late Cenozoic climate, Nature 359(1992) 117-122.

[5] C.H. Lear, H. Elderfield, P.A. Wilson, A Cenozoic seawater Sr/Ca record from benthic foraminiferal calcite and its application in determining global weathering fluxes, Earth and Planetary Science Letters 208(2003) 69-84.

[6] F.J. Sierro, J.A. Flores, G. Francés, A. Vazquez, R. Utrilla, I. Zamarreno, H. Erlenkeuser, M.A. Barcena, Orbitally controlled oscillations in planktic communities and cyclic changes in western Mediterranean hydrography during the Messinian, Paleogeography, Paleoclimatology, Paleoecology 190(2003) 289316.

[7] F.J. Hilgen, W. Krijgsman, C.G. Langereis, L.J. Lourens, A. Santarelli, W.J. Zachariasse, An astronomical (polarity) time scale for the Late Miocene, Earth and Planetary Science Letters 136(1995) 495-510.

[8] A. Lees, A.T. Buller, Modern temperate-water and warm-water shelf carbonate sediments contrasted, Marine Geology 13(1972) M67-M73.

[9] C. Betzler, T.C. Brachert, J. Nebelsick, The warm-temperate carbonate province - A review of the facies, zonations and deliminations, Courier Forschungsinstitut Senckenberg 201(1997) 83-99.

[10] N.P. James, The cool water carbonate depositional realm, Society for Sedimentary Geology, Special Publication 56(1997) 1-20.

[11] T.C. Brachert, C. Betzler, J.C. Braga, J.M. Martín, Record of climatic change in neritic carbonates: Turnovers in biogenic associations and depositional modes (Upper Miocene, southern Spain), Geologische Rundschau 85(1996) 327-337.

[12] T.C. Brachert, N. Hultzsch, A.C. Knoerich, U.M.R. Krautworst, O. Stückrad, Climatic signatures in shallow water carbonates: High-resolution stratigraphic correlation in structurally controlled carbonate buildups (Late Miocene, SSpain), Palaeogeography, Palaeoclimatology, Palaeoecology 175(2001) 211237.

[13] W. Schlager, Sedimentology and sequence stratigraphy of reefs and carbonate platforms, a short course, The American Association of Petroleum Geologists, Continuing Education Course Note Series 34(1992) 1-71.

[14] W. Schlager, Scaling of sedimentation rates and drowning of reefs and carbonate platforms, Geology 27(1999) 183-186.

[15] E.R.M. Druffel, Geochemistry of corals: Proxies of past ocean chemistry, ocean circulation, and climate, Proceedings National Academy of Sciences USA 94(1997) 8354-8361. 
[16] M.K. Gagan, L.K. Ayliffe, J.W. Beck, J.E. Cole, E.R.M. Druffel, R.B. Dunbar, D.P. Schrag, New views of tropical paleoclimates from corals, Quaternary Science Reviews 19(2000) 45-64.

[17] A. Grottoli, Past climate from corals, in: J. Steele, S. Thorpe, K. Turekian, (Eds), Encyclopedia of ocean sciences, 2001, pp. 2098-2107.

[18] T. Felis, J. Pätzold, Climate reconstructions from annually banded corals, in: M. Shiyomi, H. Kawahata, H. Koizumi, A. Tsuda, Y. Awaya, (Eds), Global environmental change in the ocean and on land, Terrapub, Tokyo, 2004, pp. 205-227.

[19] B.R. Constantz, The primary surface area of corals and variations in their susceptibility to diagenesis, in: J.H. Schroeder, B.H. Purser, (Eds), Reef Diagenesis, Springer-Verlag, New York, 1986, pp. 53-76.

[20] L.M. Roulier, T.M. Quinn, Seasonal- to decadal-scale climatic variability in southwest Florida during the middle Pliocene: Inferences from a coralline stable isotope record, Paleoceanography 10(1995) 429-443.

[21] M. Reuter, T.C. Brachert, K.F. Kroeger, Diagenesis of growth bands in fossil scleractinian corals: Identification and modes of preservation, Facies 51(2005) 155-168.

[22] N.J. Abram, J.M. Webster, P.J. Davies, W.C. Dullo, Biological response of coral reefs to sea surface temperature variation: evidence from the raised Holocene reefs of Kikai-jima (Ryukyu Islands, Japan), Coral Reefs 20(2001) 221-234.

[23] M. Esteban, An overview of Miocene reefs from Mediterranean areas: General trends and facies models, in: E.K. Franseen, Esteban, M., Ward, W.C., Rouchy, J.-M., (Ed), Models for carbonate stratigraphy from the Miocene reef complexes of Mediterranean regions, Concepts in Sedimentology and Paleontology 5, Society for Sedimentary Geology, Tulsa, 1996, pp. 3-54.

[24] L.J. Lourens, F.J. Hilgen, Long-periodic variations in the earth's obliquity and their relation to third-order eustatic cycles and late Neogene glaciations, Quaternary International 40(1997) 43-52.

[25] S.J. Schenau, A. Antonarakou, F.J. Hilgen, L.J. Lourens, I.A. Nijenhuis, C.H. van der Weijden, W.J. Zachariasse, Organic-rich layers in the Metochia section (Gavdos, Greece): evidence for a single mechanism of sapropel formation during the last 10My, Marine Geology 153(1999) 117-135.

[26] J.W. Hurrell, Decadal trends in the North Atlantic Oscillation: regional temperatures and precipitation, Science 269(1995) 676-679.

[27] D.W.J. Thompson, J.M. Wallace, Regional climate impacts of the Northern Hemisphere Annular Mode, Science 293(2001) 85-89.

[28] R. D'Arrigo, H.M. Cullen, A 350-year (AD 1628-1980) reconstruction of Turkish precipitation, Dendrochronologia 19(2001) 169-177.

[29] T. Felis, J. Pätzold, Y. Loya, M. Fine, A.H. Nawar, G. Wefer, A coral oxygen isotope record from the northern Red Sea documenting NAO, ENSO, and North Pacific teleconnections on Middle East climate variability since the year 1750, Paleoceanography 15(2000) 679-694.

[30] N. Rimbu, G. Lohmann, T. Felis, J. Pätzold, Arctic oscillation signature in a Red Sea coral, Geophysical Research Letters 28(2001) 2959-2962.

[31] T. Felis, G. Lohmann, H. Kuhnert, S.J. Lorenz, D. Scholz, J. Pätzold, S.A. AlRousan, S.M. Al-Moghrabi, Increased seasonality in Middle East temperatures during the last interglacial period, Nature 429(2004) 164-168. 
[32] A. Micheels, Late Miocene climate modelling with ECHAM4/ML - The effects of the palaeovegetation on the Tortonian climate, Universität Tübingen, 2003.

[33] A. Steppuhn, A. Micheels, G. Geiger, V. Mosbrugger, Reconstructing the Late Miocene climate and oceanic heat flux using the AGCM ECHAM4 coupled to a mixed-layer ocean model with adjusted flux correction, Palaeogeography, Palaeoclimatology, Palaeoecology accepted(2004).

[34] H. Füchtbauer, (Ed) Sedimente und Sedimentgesteine. Sediment-Petrologie, Teil II, E. Schweizerbart'sche Verlagsbuchhandlung (Nägele u. Obermiller), Stuttgart, 1988, $1141 \mathrm{pp}$.

[35] T. McConnaughey, $13 \mathrm{C}$ and $18 \mathrm{O}$ isotopic disequilibrium in biological carbonates: I. Patterns, Geochimica Cosmochimica Acta 53(1989) 151-162.

[36] M.K. Gagan, A.R. Chivas, P.J. Isdale, High-resolution isotopic records from corals using ocean temperature and mass-spawning chronometers, Earth and planetary science letters 121(1994) 549-558.

[37] H. Craig, Isotopic composition and origin of the Red Sea and Salton Sea geothermal brines, Science 154(1966) 1544-1548.

[38] M. Ghil, M.R. Allen, M.D. Dettinger, K. Ide, D. Kondrashov, M.E. Mann, A.W. Robertson, A. Saunders, Y. Tian, F. Varadi, P. Yiou, Advanced spectral methods for climate time series, Review of Geophysics 40(2002).

[39] D. Paillard, L. Labeyrie, P. Yiou, Macintosh program performs time-series analysis, EOS Transactions of the American Geophysical Union 77(1996) 379.

[40] P.N. Pearson, M.R. Palmer, Atmospheric carbon dioxide concentrations over the past 60 million years, Nature 406(2000) 695-699.

[41] J. van der Burgh, H. Visscher, D.L. Dilcher, W.M. Kürschner, Paleoatmospheric Signatures in Neogene Fossil Leaves, Science 260(1993) 1788-1790.

[42] K.L. Bice, C.R. Scotese, D. Seidov, E.J. Barron, Quantifying the role of geographic change in Cenozoic ocean heat transport using uncoupled atmosphere and ocean models, Palaeogeography, Palaeoclimatology, Palaeoecology 161(2000) 295-310.

[43] U. Mikolajewicz, E. Maier-Reimer, T.J. Crowley, K.J. Kim, Effect of Drake and Panamanian gateways on the circulation of an ocean model, Palaeoceanography 8(1993) 409-426.

[44] P.T. Meijer, R. Slingerland, M.J.R. Wortel, Tectonic control on past corculation of the Mediterranean Sea: A model study of the Late Miocene, Paleoceanography 19(2004) 19.

[45] C. Perrin, Tertiary: The emergence of modern reef ecosystems, in: W. Kiessling, E. Flügel., (Eds), Phanerozoic reef patterns, SEPM Special Publication 72, Society for Sedimentary Geology, Tulsa, 2002, pp. 587-621.

[46] F. Rögl, F. Steininger, Neogene Paratethys, Mediterranean and Indo-Pacific seaways: Implications for the paleobiogeeography of marine and terrestrial biotas, in: P. Brenchley, (Ed), Fossils and climate, Wiley and sons Ltd., New York, 1984, pp. 171-179.

[47] M. Sachse, B.A.R. Mohr, Eine obermiozäne Makro- und Mikroflora aus Südkreta (Griechenland), und deren paläoklimatische Interpretation.- Vorläufige Betrachtungen, Neues Jahrbuch für Geologie und Paläontologie - Abhandlungen 200(1996) 149-182.

[48] F.-J. Hilgen, H. Abdul-Aziz, W. Krijgsman, I. Raffi, E. Turco, Integrated stratigraphy and astronomical tuning of the Serravallian and lower Tortonian at 
Monte dei Corvi (middle-upper Miocene, northern Italy), Palaeogeography, Palaeoclimatology, Palaeoecology 199(2003) 229-264.

[49] H.M. Cullen, P.B. deMenocal, North Atlantic influence on Tigris-Euphrates streamflow, International journal of climatology 20(2000) 853-863.

[50] J.E. Meulenkamp, M. Dermitzakis, E. Georgiadou-Dikeoulia, H.A. Jonkers, H. Böger, Field guide to the Neogene of Crete, Publications of the Department of Geology and Palaeontology, University of Athens, Athens, 1979, p. 32.

[51] M. Sachse, Die Makrilia Flora (Kreta, Griechenland) - Ein Beitrag zur neogenen Klima- und Vegetationsgeschichte des östlichen Mittelmeergebietes, Eidgenössische Technische Hochschule, 1997.

[52] G. Zidianakis, B. Mohr, C. Fassoulas, The Late-Miocene flora Vrysses, Western Crete - A contribution to the climate and vegetation history, 5th International Symposium on Eastern Mediterranean Geology, Thessaloniki, Greece, 2004, pp. S5-S9.

[53] M. Reuter, T.C. Brachert, K.F. Kroeger, Shallow-marine carbonates of the tropical - temperate transition zone: effects of hinterland climate and basin physiography (Late Miocene, Crete/Greece), in: H.M. Pedley, S. Carannante, (Eds), Coolwater Carbonates, Geological society of London, Special Publication, Geological Society of London, London, 2006.

[54] K.F. Kroeger, Sedimentary environments and climate change: a case study (late Miocene, central Crete), Dissertation, Johannes Gutenberg-Universität, 2004.

[55] L. Pomar, W.C. Ward, D.G. Green, Upper Miocene reef complexes of the Llucmajor area, Mallorca, Spain, in: E.K. Franseen, M. Esteban, W.C. Ward, J.M. Rouchy, (Eds), Models for carbonate stratigraphy from Miocene reef complexes of Mediterranean regions, Concepts in Sedimentology and Paleontoogy 5, Society for Sedimentary Geology, Tulsa, 1996, pp. 191-225.

[56] C. Perrin, D.W.J. Bosence, B. Rosen, Quantitative approaches to palaeozonation and palaeobathymetry of corals and coralline algae in Cenozoic reefs, in: D.W.J. Bosence, P.A. Allison, (Eds), Marine palaeoenvironmental analysis from fossils, Geological Society Special Publication 83, The Geological Society, London, 1995, pp. 181-229.

[57] D.W. Knutson, R.W. Buddemeier, S.V. Smith, Coral chronometers: seasonal growth bands in reef corals, Science 177(1972) 270-272.

[58] J.M. Lough, D.J. Barnes, Environmental controls on growth of the massive coral Porites, Journal of Experimental Marine Biology and Ecology 245(2000) 225243.

[59] T.C. Brachert, M. Reuter, K.F. Kroeger, J.M. Lough, Coral growth bands: A new and easy to use palaeothermometer in paleoenvironment analysis and paleoceanography, Paleoceanography(submitted).

[60] D.M. Aïssaoui, Botryoidal aragonite and its diagenesis, Sedimentology 32(1985) 345-361.

[61] R. Enmar, M. Stein, M. Bar-Matthews, E. Sass, A. Katz, B. Lazar, Diagenesis in live corals from the Gulf of Aqaba. I. The effect on paleo-oceanography tracers, Geochimica et Cosmochimica Acta 64(2000) 3123-3132.

[62] H.V. McGregor, M.K. Gagan, Diagenesis and geochemistry of Porites corals from Papua New Guinea: Implications for paleoclimate reconstruction, Geochimica et Cosmochimica Acta 67(2003) 2147-2156. 
[63] S.M. Weil, R.W. Buddemeir, S.V. Smith, P.M. Kroopnik, The stable isotopic composition of coral skeletons: control by environmental variables, Geochimica et Cosmochimica Acta 45(1981) 1147-1153.

[64] T. Watanabe, M. Minagawa, O. Tadamichi, A. Winter, Pretreatment of coral aragonite for $\mathrm{Mg}$ and $\mathrm{Sr}$ analysis: Implications for coral thermometers, Geochemical journal 35(2001) 265-269.

[65] G. Wefer, W.H. Berger, Isotope paleontology: growth and composition of extent calcareous species, Marine Geology 100(1991) 207-248.

[66] T. Felis, J. Pätzold, Y. Loya, G. Wefer, Vertical water mass mixing and plankton blooms recorded in skeletal stable carbon isotopes of a Red Sea coral, Journal of Geophysical Research 103(1998) 30731-30739.

[67] M. Rosenfeld, R. Yam, A. Shemesh, Y. Loya, Implication of water depth on stable isotope composition and skeletal density patterns in a Porites lutea colony: results from a long-term translocation experiment, Coral Reefs 22(2003) 337-345.

[68] R. Hofrichter, Das Mittelmeer. Fauna, Flora, Ökologie, Spektrum Akademischer verlag, Heidelberg, 2002, 607 pp.

[69] R.G. Fairbanks, R.E. Dodge, Annual periodicity of the ${ }^{18} \mathrm{O} /{ }^{16} \mathrm{O}$ and ${ }^{13} \mathrm{C} /{ }^{12} \mathrm{C}$ ratios in the coral Montastrea annularis, Geochimica et Cosmochimica Acta 43(1979) 1009-1020.

[70] T.M. Quinn, F.W. Taylor, T.J. Crowley, S.M. Link, Evaluation of sampling resolution in coral stable isotope records: A case study using records from New Caledonia and Tarawa, Paleocenanography 11(1996) 529-542.

[71] A.W. Tudhope, C.P. Chilcott, M.T. McCulloch, E.R. Cook, J. Chappell, R.M. Ellam, D.W. Lea, J.M. Lough, G.H. Shimmield, Variability in the el Ninosouthern Oscillation through a Glacial-Interglacial cycle, Science 291(2001) 1511-1517.

[72] C. Guernet, L'évolution paléogéographique et tectonique de la Grèce au Miocène: Un essai de synthèse, Revue de Géographie Physique et de Géologie Dynamique 2 20(1978) 95-108.

[73] J.C. Braga, J.M. Martín, B. Alcala, Coral reefs in coarse-terrigenous sedimentary environments (Upper Tortonian, Granada Basin, southern Spain), Sedimentary Geology 66(1990) 135-150.

[74] E.K. Franseen, M. Esteban, W.C. Ward, J.-M. Rouchy, (Eds), Models for carbonate stratigraphy from Miocene reef complexes of Mediterranean regions, Society for Sedimentary Geology, Tulsa, 1996, $391 \mathrm{pp}$.

[75] F. Wrobel, Das Lorca-Becken (Obermiozän, SE-Spanien), Geologische Beiträge Hannover 1(2000) 1-141.

[76] K. Dethloff, W. Dorn, A. Rinke, K. Fraedrich, M. Junge, E. Roeckner, V. Gayler, U. Cubasch, J.H. Christensen, The impact of Greenland's deglaciation on the Arctic circulation, Geophysical Research Letters 31(2004) L19201 19201-19204.

[77] J.M. Gregory, P. Huybrechts, S.C.B. Raper, Threatened loss of the Greenland ice-sheet, Nature 428(2004) 616.

[78] IPCC, Climate change 2001: The scientific basis - contribution of Working Group I to the third assessment report of the Intergovernmental Panel on Climate Change, Cambridge University Press, Cambridge, 2001. 
[79] T.J. Crowley, J.C. Zachos, Comparison of zonal temperature profiles for past warm time periods, in: B. Huber, K.G. MacLeod, S.L. Wing, (Eds), Warm Climates in Earth History, Cambridge Univ. Press, Cambridge, 2000, pp. 50-76.

\section{Figures:}

Fig. 1. Location of Psalidha fossil reef sites, Rouvas Municipality, Central Crete (Greece). (A) Geological overview map; inset shows location of geological map shown in (B). Modified from [50]. (C) Detailed geological map of the Psalidha coral build-up with locations of coral sites 1 (specimens P1, P3, P4) and 2 (specimen P2). GPS coordinates for Coral Site 1: N 35.08446\%/E 024.96668 ${ }^{\circ}$; Coral Site 2: N 35.08424\%/E $024.96094^{\circ}$.

Fig. 2 Weathering profile of Psalidha coral build-up at Coral Site 2. A poorly classified sandstone and conglomerate drapes over the surface of the biostrome thus preserving the original growth topography. Corals preserved in original aragonite occur along the contact of the build-up and coarse clastics. Retention of original aragonite is believed to correspond with a tight seal formed by silty sandstone on top of the buildup.

Fig. 3. Cross-section of large fragment of massive Porites (P2) and location of 67 years isotope transect. Convex upward "light" and "dark" bands represent annual growth bands. Notice abundant fractures orientated preferentially parallel to the original growth axes. Squares numbered D1 - 5 show x-ray diffraction samples. Photograph taken from wet slab. Psalidha Coral Reef Site 2, early Tortonian. 
Fig. 4. X-ray photographs (positive print) from two slabs of Coral P2. Alternating bands of high (dark colour) and low skeletal density (light colour) are visible. One year is represented by one density couplet. Irregular white lines crossing the growth fabrics represent fractures. White arrows mark fractures filled with cryptocrystalline carbonate (dark shade).

Fig. 5. Microscopic aspects of the coral skeleton. (A) and (B): Thin section photomicrograph of the skeleton in reflected (A) and transmitted (B) light showing conspicuous couplets of dark and light bands. A: The light material in this photograph is the coral skeleton. The skeleton is compact and thick in the light bands (HD) and comparatively more delicate and thinner in the dark bands (LD). Dark reflection between skeleton is from impregnation with epoxy resin. B: In transmitted plane light, the growth banding is hardly visible. Diagenetic overgrowths and recrystallizations are not visible at this magnification and are therefore volumetrically not significant. Both photographs show same segment of coral P 2. (C) to (F): SEM micrographs from fracture surfaces of the skeleton of coral P 2. (C): Overview of pristine aragonite textures with radial arrangement of aragonite fibres and dissepiments (DI) showing little signs of dissolution nor recrystallization. Centres of calcification have undergone some partial dissolution. (D): Close-up from $\mathrm{C}$ showing radial arrangement of aragonite fibres. The skeleton is affected by abundant microborings, which have not been filled by subsequent cementation (BO). The tiny crystallites of the dissepiments (DI) form meniscate diaphragms in continuity with fans of aragonite fibres (arrows) and therefore represent an original growth fabric. Dissepiments (DI) composed of tiny aragonite crystals $(1-2 \mu \mathrm{m})$ do exhibit little evidence for dissolution. E: Planned-smooth surface of the skeleton, formed in contact with the calcioblastic tissue of the coral (MC), not 
overgrown by cements. F: Thin crusts of syntaxial in vitro aragonite cements (1-2 $\mu \mathrm{m})$ formed deeper in the coral (MC), after withdrawal of the calcioblastic tissue from the skeleton during growth. Smooth surfaces (CT) remained, where tissue remained in prolonged contact with the skeleton. Note smooth and edged distal ends of aragonite fibres at fasciculi boundaries.

Fig. 6. High-resolution Porites-coral stable oxygen and carbon isotopic records $\left(\delta^{18} \mathrm{O}\right.$ and $\delta^{13} \mathrm{C} \%$ vs. V-PDB) from Psalidha coral Site 1. Black horizontal line and gray shade show mean and maximum variation in $\delta^{18} \mathrm{O}$ composition documented in coral P2 (Fig. 7). A: Four year record with a bimonthly resolution, coral P 3. B: 12 years of total record within two parallel transects with a quarterly resolution, coral P 4. C: X-ray photograph (positive) showing density bands and location of isotope records shown in Fig. 6B.

Fig. 7. Multidecadal (67 years) record of $\operatorname{coral} \delta^{18} \mathrm{O}$ with a near quarterly resolution. Porites P 2, Coral Site 2. Black horizontal lines show mean $\delta^{18} \mathrm{O}$ of corals P3 and P4 (Fig. 6).

Fig. 8. Spectral properties of the 67-year Late Miocene coral $\delta^{18} \mathrm{O}$ time series from coral P 2. Multitaper method spectral analysis with red noise null hypothesis [38] (number of tapers: 3, bandwidth parameter: 2; 95\% significance level is indicated) of the quarterly interpolated, detrended and normalized coral $\delta^{18} \mathrm{O}$ time series. 
Fig. 9. (A) Near-surface air temperature anomaly showing the difference between Tortonian (Late Miocene) and modern winter climate (December, January, February), based on simulations with the ECHAM4/ML atmospheric circulation model coupled to mixed layer ocean model $[32,33]$. Earliest Tortonian reefs (red dots) indicate winter $\mathrm{SST}>18^{\circ} \mathrm{C}$ and single coral colonies in non-reefal carbonates (orange dots) are assumed to reflect winter SST of $\sim 18{ }^{\circ} \mathrm{C}$. (B, C) Relationship between modelled interannual eastern Mediterranean climate variability and modelled North AtlanticEuropean sea level pressure (SLP) during the Tortonian, based on the ECHAM4/ML model $[32,33]$. (B) Composite map for modelled Tortonian sea surface temperature in the eastern Mediterranean $\left(20^{\circ}-30^{\circ} \mathrm{E} ; 35^{\circ}-40^{\circ} \mathrm{N}\right)$ and modelled SLP for winter (December, January, February; DJF). (C) Same as in B, but for modelled Tortonian evaporation in the eastern Mediterranean (DJF). Near surface wind anomaly is schematically represented as white arrows. White cross marks Crete. 

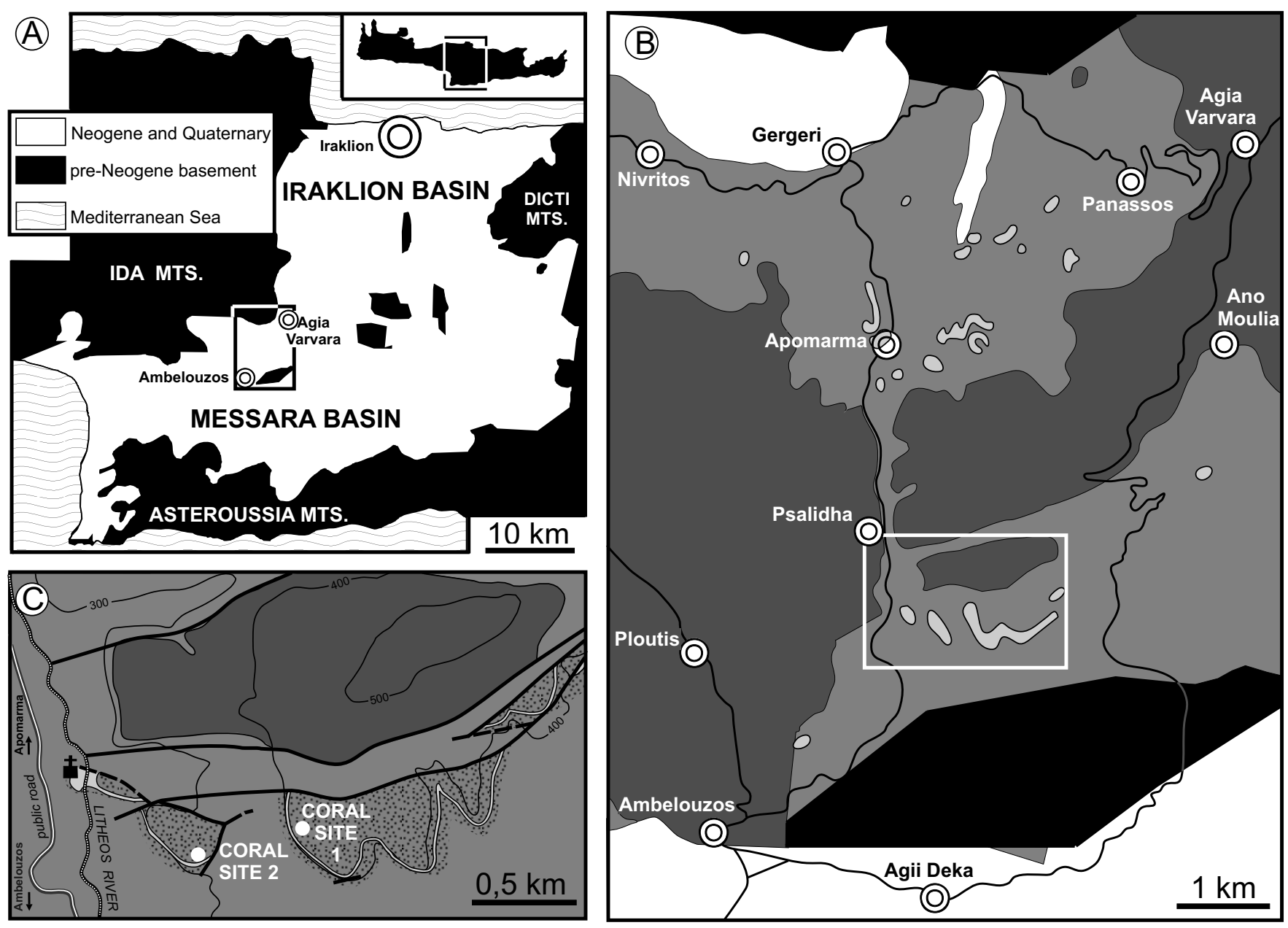

pre-Neogene

Ambelouzos Fm.

coastal

onglomerate

coral

build up

Varvara Fm.. (late Tor-

Alluvial

Figure 1

Brachert et al. 


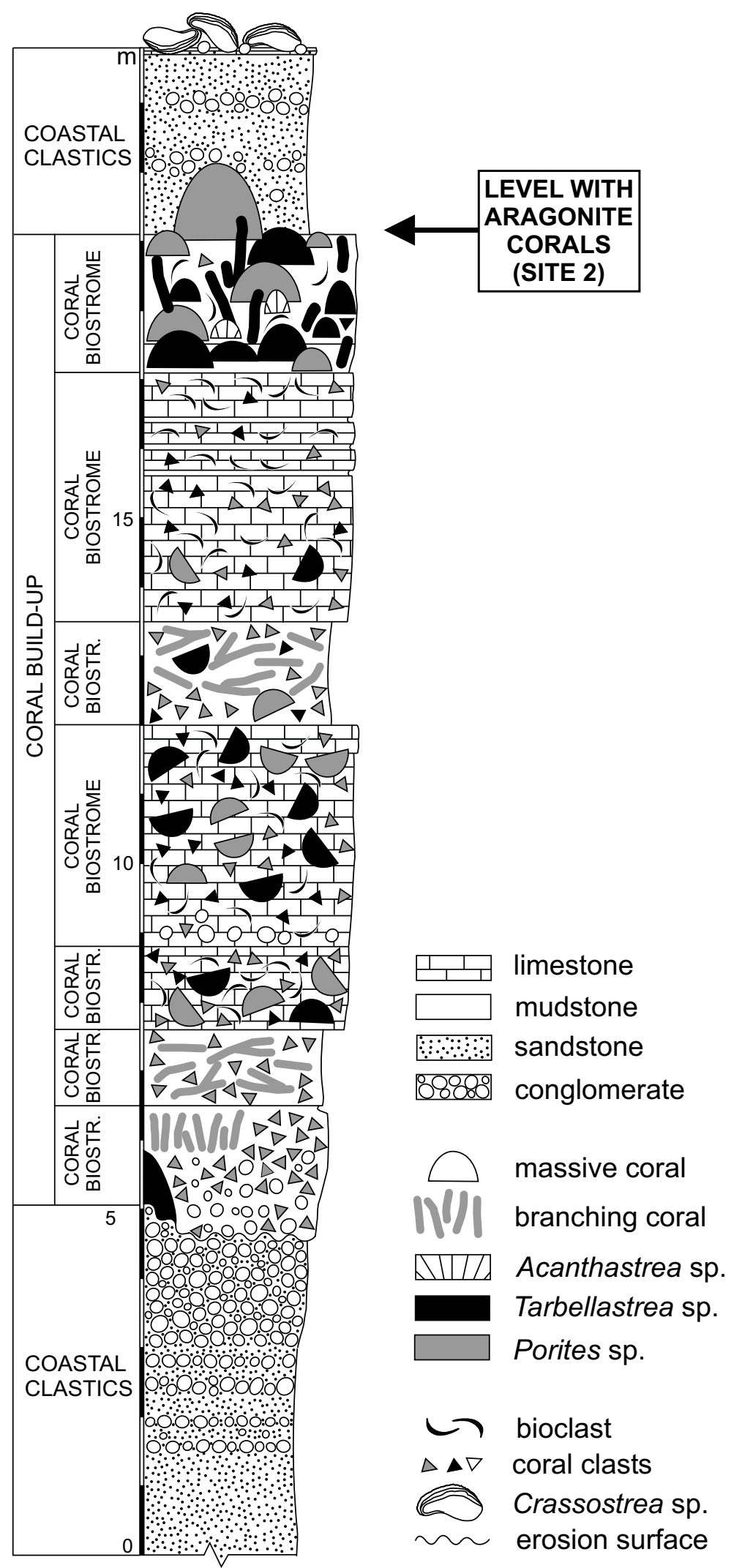




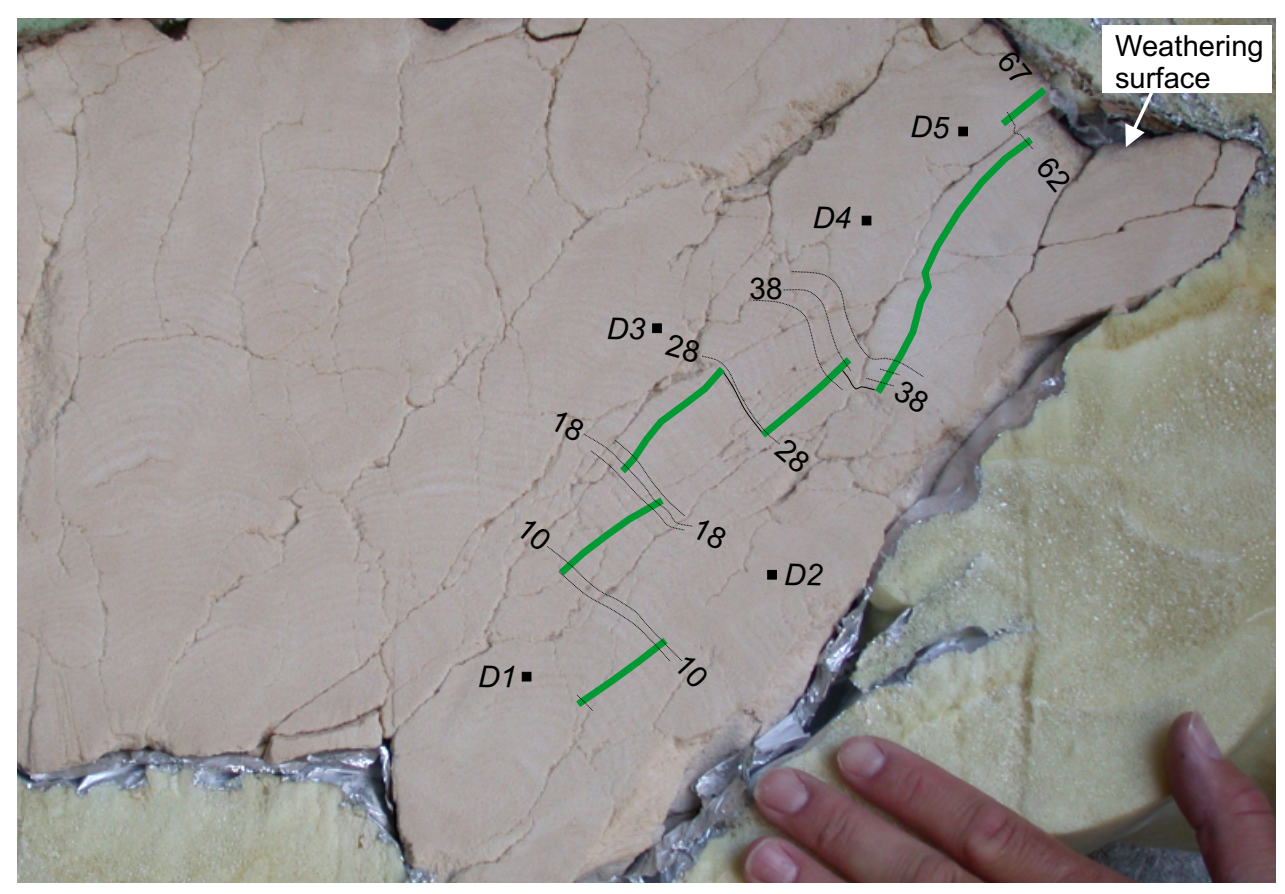

Fig. 3 (Brachert et al.) 

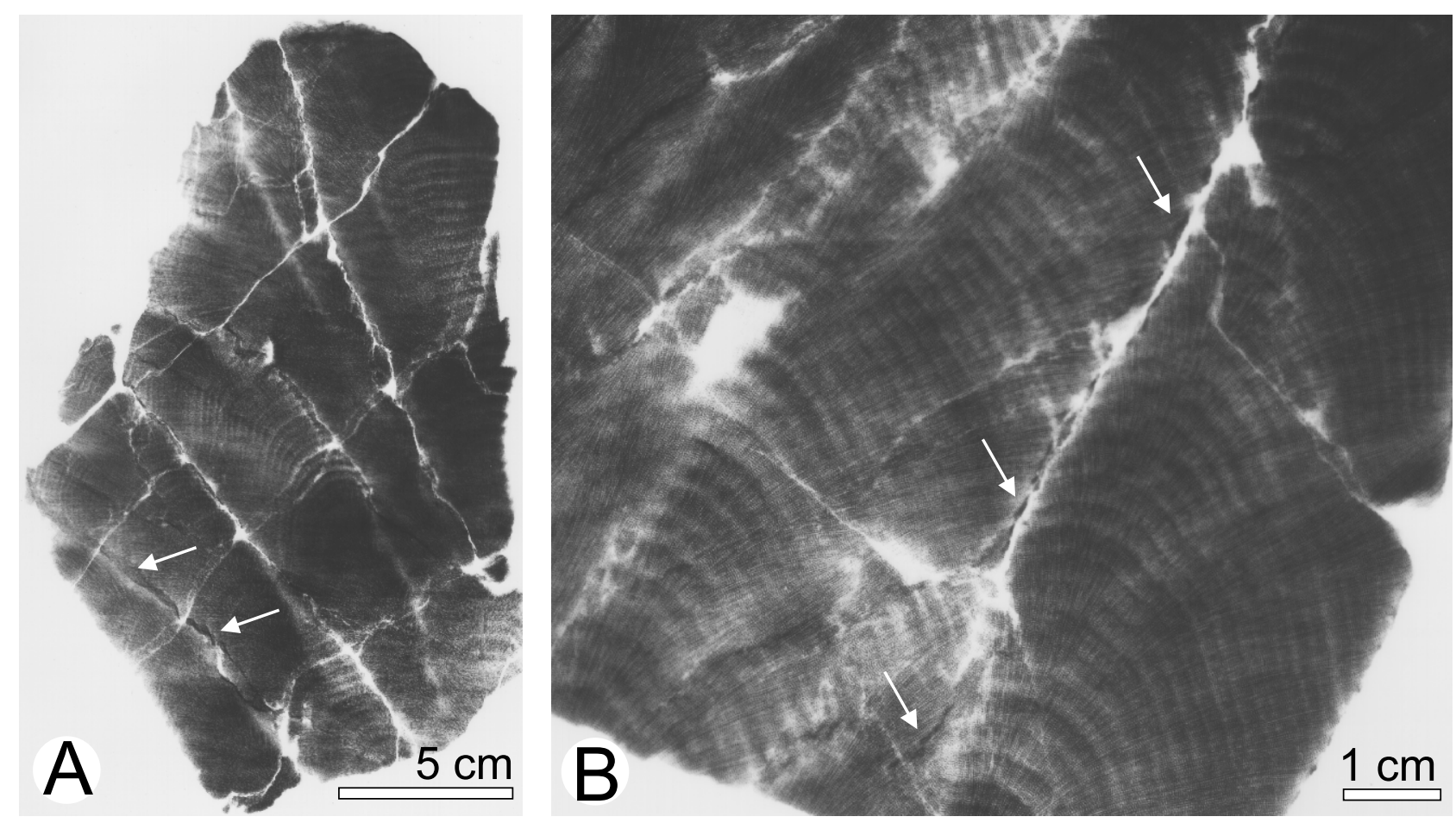

Fig. 4 Brachert et al. 

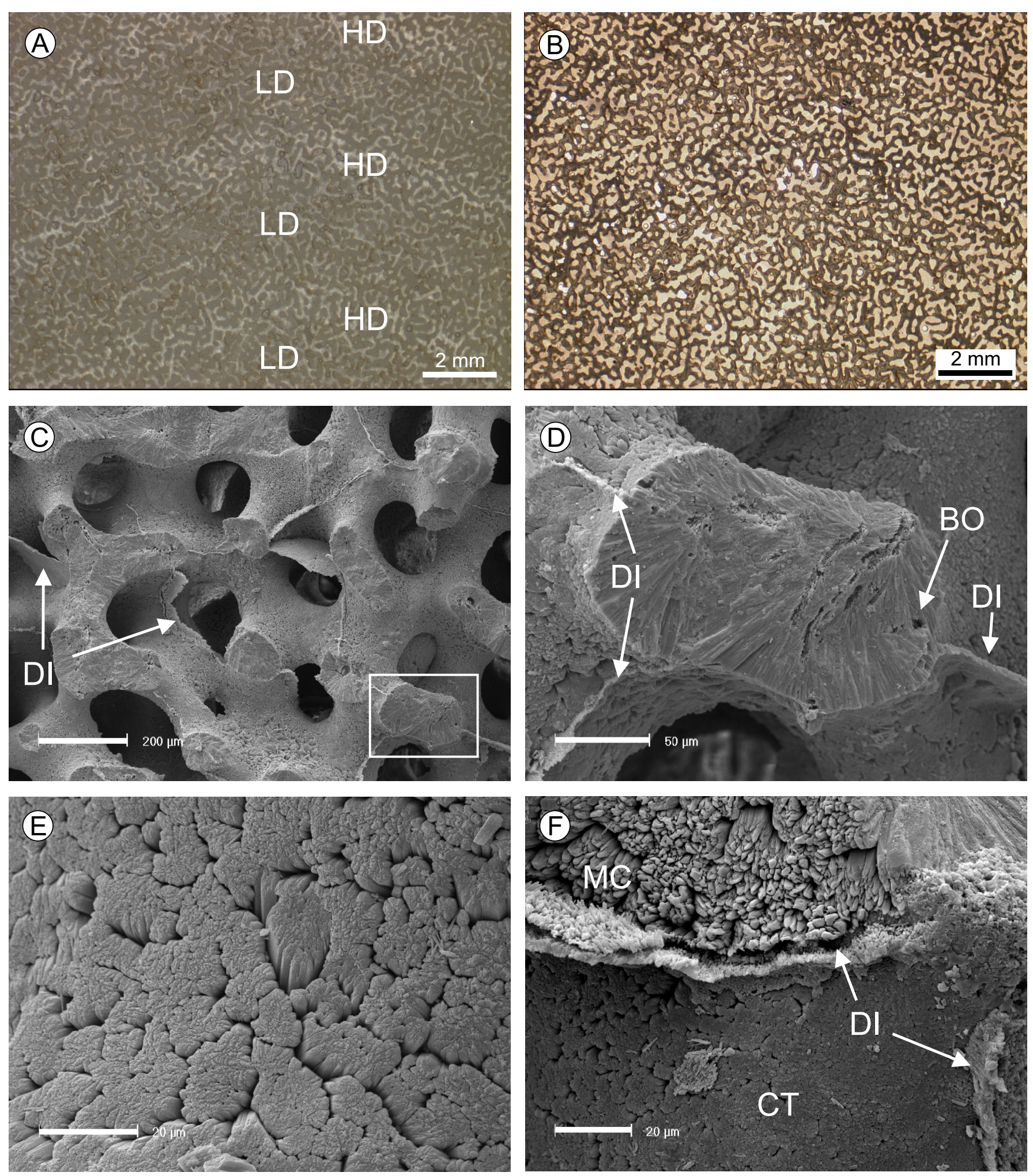

Fig. 5

Brachert et al. 

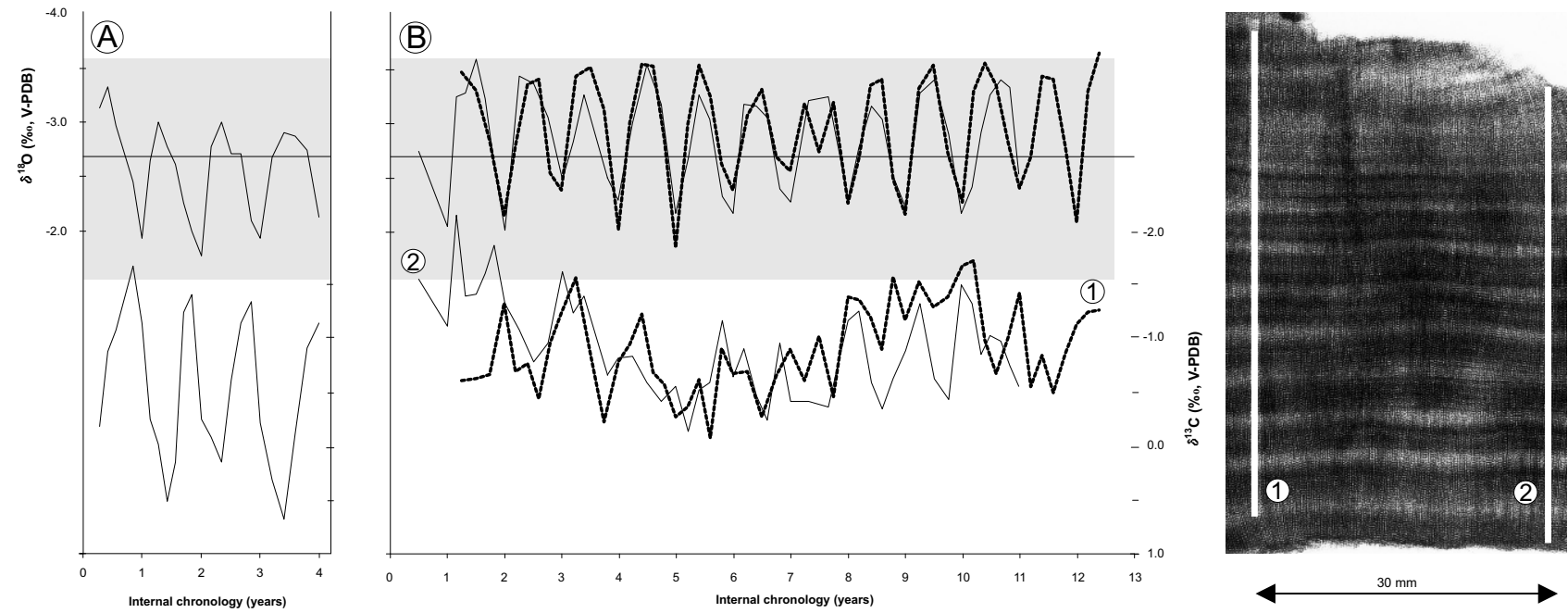

Figure 6 Brachert et al. 


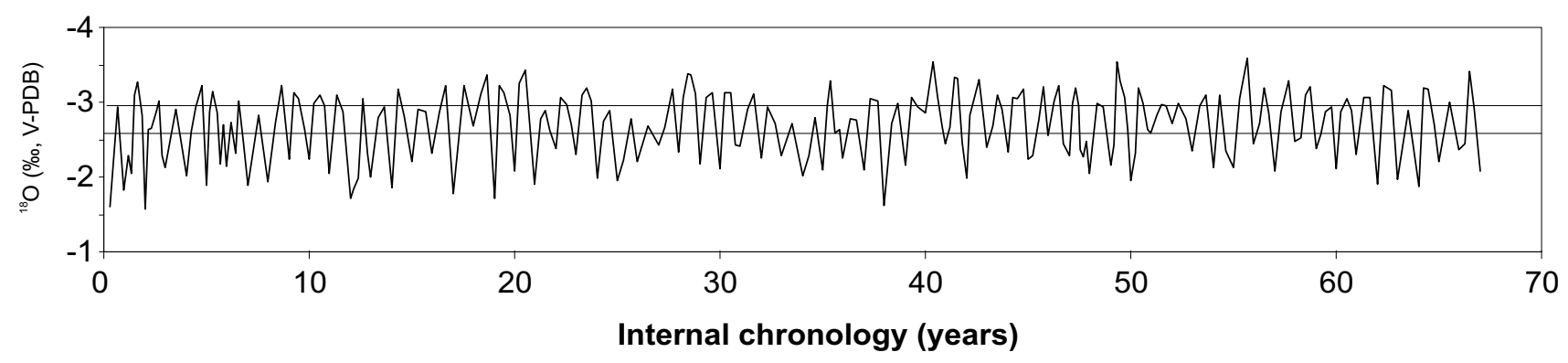

Figure 7

Brachert et al. 